УДК 364-057.36

DOI: https://doi.org/10.18524/2707-0409.2020.1(51).225374

\title{
Гопкало Ю.
}

молодший науковий співробітник лабораторії прикладної психології освіти, Український науково-методичний центр практичної психології і соціальної роботи e-mail: hopkaloyuliia@gmail.com

ORCID: 0000-0003-4642-6579

\section{ЗАСТОСУВАННЯ ТІАЕСНО ОРІЕНТОВАНОЇ ПСИХОТЕРАПIÏ ЯК ОАНОГО 3 МЕТОАІВ У РОБОТІ 3 АІТЬМИ ТА СІМ'ЯМИ, ЩО ПЕРЕЖИАИ ТРАВМУЮЧІ ПОАIÏ}

У статті розглянуто й обгрунтовано теоретичні та методичні основи організації групових форм роботи з психотравмою в осіб, які постраждали внаслідок воєнних дій, на основі впровадження методів тілесно орієнтованої психотерапії.

Групові методи у роботі з посттравматичними стресовими розладами у роботі з дітьми та сім'ями, що опинилися у складній життєвій ситуації внаслідок воєнних дій, є системою психотерапевтичного впливу, що оптимально поєднує тілесно орієнтовану психотерапію з елементами символдрами, психологічний дебрифінг, поведінкові методи психотерапії, танцювальнорухову психотерапію, арт-терапію, психотренінг, фармакотерапію та інші методи, спрямовані на роботу з клінічними проявами психотравми. Метод тілесно орієнтованої психотерапії у роботі з дітьми та сім'ями, що постраждали від психотравмуючих подій, може виступати провідним як в роботі з віддаленими клінічними проявами, так і для попередження розвитку ПТСР, в роботі з порушенням психічних і тілесних аспектів функціонування, вирішення внутрішньоособистісних конфліктів; визначення рівня адекватності самосприйняття і самооцінки; зниження рівня особистісної тривожності, психічної напруженості, емоційної лабільності.

Тілесно орієнтована психотерапія розширює можливості психотерапевтичного впливу тим, що розглядає особистість в єдності їі психосоціального та біологічного функціонування. Її 
використання допомагає дітям та сім'ям, що пережили травмуючі події, за допомогою рухових психотехнік більш точно розпізнати і вербалізувати власні емоції, пережити заново свій минулий емоційний досвід, сприяючи тим самим розширенню сфери самопізнання та формування більш емоційного благодатного ставлення до себе. Окрім цього, вона робить значний внесок у подальший розвиток уявлень про механізм лікувальної дії психотерапії, оскільки зміни, що відбуваються з клієнтами (дітьми та сім'ями, що пережили травмуючи дії), і є кінцевою метою психотерапевтичного впливу, стосуються різних рівнів функціонування організму й особистості.

Ключові слова: особи, які постраждали внаслідок воєнних дій, психотравма, тілесно орієнтована психотерапія, методи.

Вступ та сучасний стан досліджуваної проблеми. Особи, що зазнали впливу психотравмуючих подій, пережили екстремальні ситуації, зокрема і воєнні дії, можуть зазнати тяжких наслідків, що спричинюють серйозні порушення психічного здоров'я, нервові зриви, тривалі депресії, тривалу дезадаптацію і в найгіршому випадку - відмову від життя, суїцид. Професійна діяльність психолога часто пов'язана з наданням психологічної допомоги дітям та сім'ям, які пережили психотравмуючі події. До таких подій відносять ситуації, пов’язані із загрозою життю (або її благополуччю), честі, гідності, що стосуються людини та їі близьких [5, с. 105]. Травмуючий вплив на психіку може спричинити загибель не лише інших (незнайомих) людей, а й ворогів. Психологічну травму також викликають ситуації навмисного обману, шахрайства, що позначається на втраті довіри взагалі до людей, до світу, до розвитку кризових станів. Переживши травмуючу ситуацію, людина виконує величезну внутрішню роботу, спрямовану на переоцінку самої себе, свого минулого, перебудову звичних раніше форм поведінки, поглядів на майбутнє тощо [7, с. 204]. У психіатрії для позначення захворювань, викликаних психотравмуючими подіями, використовується термін психогенії [2, с. 83]. У сферах психології, що перебувають на стику психології та медицини (і в окремих психологічних напрямках, наприклад, в психоаналізі), частіше використовується термін 
«психічна травма», що позначає переживання, викликані важкою травмуючою подією, що травмує психіку і знаходить відображення у певній симптоматиці [16, с. 131].

Для надання ефективної професійної психологічної допомоги при травматичному стресі, кризових станах, важких психотравмах дітям та сім'ям, що пережили травмуючи події, необхідно використовувати комплексний підхід. У певних випадках можливо і необхідно використання раціональних методів, в інших - ефективніше застосовувати тілесно орієнтований підхід, роботу з образами, звертатися до несвідомого.

Сучасна біопсихосоціальна парадигма психічних розладів зумовлює необхідність оптимізації психотерапевтичного процесу 3 дітьми та сім'ями, що пережили травмуючі події, та вимагає використання не лише принципово нових психофармакологічних препаратів, а й удосконалення психотерапевтичних програм з використанням мультимодального, інтегрального підходу. Такий підхід дає змогу поєднати прийоми і техніки різних психотерапевтичних напрямів на основі синтезу фундуючих їх етіопатогенетичних уявлень і теоретичних основ [10, с. 4].

3 огляду на це можливою $є$ інтеграція деяких тілесно зорієнтованих технік з окремими психотерапевтичними методами, зокрема такими, як групова поведінкова психотерапія, когнітивна психотерапія, психосинтез, арт-аналіз та інші [5; 7; $10 ; 12 ; 15 ; 16]$. Різноманітність тілесно зорієнтованих підходів практично не знайшла відображення в психологічній практиці, i безпосередньо-чуттєвий, тілесний досвід, який використовується в груповій тілесно орієнтованій психотерапії, як і раніше, залишається незатребуваним у психотерапії дітей та сімей, що пережили травмуючи події. Водночас тіло - це не лише матеріалізація структури особистості і психологічних проблем людини; тілесний контакт може бути зворотним зв'язком у процесах комунікації [11, с. 303]. Тілесний досвід є необхідною складовою людського існування, умовою його повноти i цілісності.

Сучасний період характеризується прагненням до розуміння людського організму як цілісної системи. Згідно з холістичним підходом всі функції організму взаємопов'язані. Розгляд 
особистості як цілого - означає розгляд особистості в усіх іiі виявах: тіло, психіка, мислення, почуття, уява, рух тощо [12, c. 53]. Це не те ж саме, що розглядати особистість як суму окремих частин. Виникає необхідність сприймати особистість як інтегроване функціонування різних аспектів цілого в часі i просторі [12, с. 70]. 3 цієї позиції вважати один аспект особистості винятковою причиною виникнення цілісної проблеми - значить штучно розділяти те, що насправді функціонує як єдність. Тілесно орієнтована психотерапія більшою мірою, ніж інші напрями психотерапії, дотримується холістичного підходу.

Незважаючи на те, що історія тілесно зорієнтованої терапії налічує майже сто років, як науковий напрям вона в Україні почала розвиватися лише в останне десятиліття, а в роботі з дітьми та сім'ями, які пережили травмуючи події, практично не використовується.

Подібний розрив між значним практичним досвідом і слабкою теоретичною базою не випадковий. Створення теорії тілесно орієнтованої психотерапії є досить трудомістким процесом, оскільки зачіпає основи психофізіологічної проблеми взаємодії душі і тіла. На практиці межі тілесно орієнтованої психотерапії необгрунтовано розширені, відбувається перетин ії з іншими, зорієнтованими на тіло людини, техніками. Це приносить значну шкоду, оскільки створює плутанину в осмисленні і цілеспрямованості застосування окремих вправ. 3 одного боку, до тілесно орієнтованої психотерапії примикають такі методи впливу на тіло, як ЛФК, психофізичні тренування, холістичний масаж, а з іншого - хореотерапія, рухова терапія, кінезіотерапія. До того ж нині поширеною є практика комбінованих методів, серед яких метод Дарбонна - поєднання рольфінга, біоенергетики та гештальт-терапії; метод Рубенфельд - комбінація методу Александера, методу Фельденкрайза і гештальттерапії; метод Майла, який поєднує гіпноз і прикладну кінезіологію; первинна терапія Янова - комбінація райхіанської терапії і гештальт-терапії.

Обговорення. Загалом у сучасній науковій літературі, як зазначає I. Ревуцька, налічується щонайменше 15 різноманітних 
підходів, визначених як «робота 3 тілом» [6, с. 133]. Деякі 3 них є суто психотерапевтичними за своєю метою, а інші - точніше визначити як методи фізичної терапії, ключовою метою яких є тілесне здоров'я.

Тілесно орієнтована психотерапія, на думку В. Баскакова, є одним з найсучасніших і ефективних напрямів в психологічній практиці. Його відмінність від всіх інших полягає в тому, що звична психологічна робота доповнюється роботою з тілом людини [1, с. 124]. Тілесно орієнтована психотерапія - це не просто заняття, спрямовані на фізичний розвиток, а й тілесно орієнтовані заняття для дітей та сімей, які в силу пережитих травмуючи подій страждають певним психосоматичними розладом або відчувають емоційні труднощі.

Доцільним у межах дослідження є звернення до наукових пошуків Ф. Рохтріха, який зазначає, що тілесно орієнтовані (рухові) методи не лише створюють певний потенціал для майбутньої роботи, а й активізують, відновлюють і вибудовують взаємодії між різними рівнями й аспектами психічної діяльності [17, с. 150]. Актуалізація та закріплення будь-яких тілесних навичок передбачає затребуваність ззовні таких психічних функцій як емоції, сприйняття, пам'ять, процеси саморегуляції тощо. Отже створюється базова передумова для їхньої повноцінної участі в оволодінні навичками навчання в подальшому. Відтак, основними завданнями тілесно зорієнтованої психотерапії є: відновлення контакту з власним тілом; розвиток невербальних компонентів спілкування з метою оптимізації психічного самопочуття у взаємодії з оточуючими; зняття бар'єрів у спілкуванні, зняття м'язової напруги; корекція емоційної сфери, ослаблення негативних емоцій; розвиток почуття згуртованості, створення емоційного комфорту.

Найвідомішими сучасними напрямами тілесної психотерапії є психологія тіла В. Райха, біоенергетичний аналіз А. Лоуен, концепція тілесного усвідомлення М. Фельденкрайза, метод інтеграції рухів Ф. Александера, метод чуттєвого усвідомлення Ш. Селвер, структурна інтеграція I. Рольф, танатотерапія В. Баскакова. Однак майже для всіх базовими є теорія моделі особистості, поняття психології розвитку, особливості про- 
тікання психічних процесів і впливу соціально-психологічних чинників на індивіда [13, с. 210].

Виклад основного матеріалу. Ці методи тілесно орієнтованої терапії не повинні бути переплутані з розвиваючими тілесними практиками та реабілітаційними методами, спрямованими на поліпшення загального соматичного i фізичного здоров'я, емоційного стану особистості за допомогою прямої механічної роботи з тілом (техніки лікувальної фізкультури, мануальні техніки, різні види масажу). Навіть низка тілесних практик, здійснюючи певний вплив на емоційну сферу особистості, не здатна пропрацювати заблоковані глибинні емоції і психологічні проблеми в межах психотерапії, що вийшли назовні.

У роботі з дітьми та сім'ями, що пережили травмуючи події, тілесно зорієнтована психотерапія спрямована на усвідомлення механізмів блокування придушених, не відредагованих емоцій, таких як гнів, роздратування, образа, страх. Їхні негативні наслідки залишаються в підсвідомості та в тілі і виявляються різними хронічними м'язовими напруженнями (так званими «м'язовими затисками», або «м'язовим панциром»), і внаслідок цього - порушенням рухливості, постави, больовими синдромами і хворобливими станами [8, с. 81].

Водночас соматичні симптоми психічних травм у дітей та сімей, що пережили травмуючи події, розглядаються як тілесні вияви їхніх переживань і поведінки. Тому тілесно орієнтована психотерапія у роботі з такою категорією клієнтів спрямована не на їхнє усунення, а на те, щоб зробити доступними переживання й усвідомлення, співвідносячи почуття і поведінку (що стали невротичними або патологічними), з їхніми життєвими уявленнями, смислами і цінностями. Тому в психотерапії з дітьми та сім'ями, що пережили травмуючі події, доцільно використовувати, окрім загальноприйнятих, і спеціальні засоби психотерапевтичного впливу, що розширюють можливості особистісного зростання й оздоровлення особистості. Наприклад, терапевтична робота 3 рухом, диханням, м'язовим тонусом, енергобалансом та функціями тіла; з енергетичними і міжособистісними кордонами; з ресурсами розвитку і відчуттям безпеки. 
У таких умовах тілесно орієнтовані психокорекційні методи у роботі з дітьми та сім'ями, що постраждали від травмуючих подій, сприяють гармонізації емоційної, інтелектуальної, вольової та фізичної складових особистості; виявленню внутрішніх потреб, бажань і почуттів; розвитку творчої активності особистості шляхом підвищення рівня власного прийняття і зниження рівня тривожності.

Відтак, тілесно орієнтована психотерапія у роботі з дітьми та сім'ями, що постраждали від травмуючих подій, є системою психотерапевтичного впливу, що оптимально поєднує тілесно орієнтовану психотерапію з елементами символодрами, раціонально-сугестивної психотерапії, поведінкової психотерапії, танцювально-рухової психотерапії, оздоровчих практик і спрямовану на роботу з клінічними проявами, особистістю і несвідомими переживаннями пацієнтів. Метою інтегративної тілесно орієнтованої психотерапії роботі з дітьми та сім'ями, що постраждали від травмуючих подій, є купірування клінічних проявів та відновлення порушених психічних і тілесних аспектів функціонування, з урахуванням несвідомих чинників, що сприяє усвідомленню витіснених потреб і конфліктів особистості, мобілізації внутрішніх ресурсів для подальшої адаптації в соціумі.

Основними принципами тілесно орієнтованої психотерапії у роботі з дітьми та сім'ями, що постраждали від травмуючих подій, є комплексний характер терапії; клінічна обгрунтованість; етапність і безперервність психотерапевтичного впливу; індивідуальний підхід з урахуванням соматичного і психічного стану клієнтів; доступність в освоєнні і самостійному використанні [17, с. 154$]$.

Важливою відмінністю тілесно орієнтованої психотерапії у роботі з дітьми та сім'ями, що постраждали від травмуючи подій, від інших напрямів є використання вербальних і невербальних психологічних засобів [4, с. 304]. Вербальні техніки використовуються з тими ж цілями, що і в основних напрямах психотерапії. Натомість у роботі з дітьми та сім'ями, що постраждали від травмуючи подій, доцільно використовувати такі невербальні технології впливу тілесно орієнтованої психо- 
терапії: демонстраційно-діагностичні, ресурсні, апробаційні i тестові. Демонстраційно-діагностичні вправи використовуються для усвідомлення дітьми та сім'ями зв'язку між діагностичною версією терапевта й їхніми когнітивними і поведінковими порушеннями, створення терапевтичних відносин з формуванням єдиного розуміння цілей і завдань терапії, їхнє мотивування на подальшу роботу. Ресурсні вправи спрямовуються на усвідомлення дітьми та їхніми сім'ями наявного власного потенціалу $з$ метою отримання доступу до нового ресурсу. Апробація технік є можливість у роботі з дітьми та сім'ями, що пережили травмуючи події, виявляти на практиці нові тілесні і поведінкові патерни [9, с. 194]. Тестові вправи використовуються для того, щоб клієнти мали змогу переконатися в наявності особистісних змін, водночас ці техніки дають ресурсний ефект.

Загальними принципами роботи 3 дітьми та сім'ями, які пережили травмуючи події, у межах тілесно зорієнтованої психотерапії є: психотерапія спрямована на встановлення довірчих терапевтичних відносин; наявність власної теорії особистості; використання вербальних і невербальних психологічних методів; наявність певної структури заняття; цілями роботи є оптимізація об'єктивних когнітивних і поведінкових ознак психічних порушень як критерій ефективності проведеної терапії [15, с. 311]. Окрім того, тілесно орієнтована психотерапія як лікувальний процес у роботі з дітьми та сім'ями, що пережили травмуючи події, охоплює такі основні етапи:

1) збір інформації з попередньою діагностикою і формулюванням терапевтичного запиту;

2) побудова діагностичних версій і вибір терапевтичної стратегії;

3) демонстраційно-діагностичний етап, що передбачає руйнування проблемних особистісних паттернів, створення конструктивних особистісних і поведінкових патернів, спостереження за динамікою;

4) посттерапевтична корекція [3, с. 214].

3 урахуванням окресленого необхідним є конструювання мультимодального методу тілесно орієнтованої терапії, який охоплює спеціально підібрані методики, спрямовані тією чи ін- 
шою мірою на запобігання безпечних умов для дітей та їхніх сімей, у яких вони могли б пережити свій негативний досвід як взаємозв'язок психічного і тілесного i, тим самим, отримати можливість для поліпшення власного функціонування в соціумі та усунення наслідків травмуючих подій $[14$, с. 600].

Заняття з тілесно зорієнтованої психотерапії у роботі з дітьми та сім'ями, що пережили травмуючи події, проводяться в три етапи, згідно з логікою групового процесу:

Перший етап спрямований на оптимізацію комунікативних можливостей і створення безпечної і довірливої атмосфери в групі, розвиток спостережницької сенситивності. На цьому етапі відбувається усвідомлення індивідуальних особливостей взаємодії з іншими через тіло. Цей етап є своєрідним інструментом збору інформації для подальшої групової та індивідуальної терапії, які проводяться паралельно.

Другий етап передбачає проведення пластичного тренінгу. Цей етап проводиться після досягнення атмосфери доброзичливості, довіри, емоційної безпеки і комфорту і спрямовується на навчання техніці релаксації, зняття м'язової напруги, навчання виявленню і довільному розслабленню групи напружених м'язів, вивільненню внутрішньої негативної енергії, що сприяє усвідомленню зв'язку тілесності й емоційних переживань. На цьому етапі ефективним є використання таких вправ: "розрядка гніву й агресії, «крик», «вивільнення шуму», «істерика». Вправа «вивільнення шуму» полягає в тому, що діти та сім'ї, що пережили травмуючи події, видають «будь-які дивні або дитячі звуки, які просяться назовні, особливо ті, які заборонялися. Вправа «крик» полягає в тому, що пацієнти набирають повні груди повітря, закривають долонями рот і кричать з усіх сил до стану повного спустошення.

Вправа «розрядка гніву й агресії» необхідна для скидання надлишкової напруги, емоційної розрядки. Вправа полягає в тому, що пацієнти складають список ситуацій і людей, які викликають або викликали гнів, після чого обирають об'єкт агресії, сідають на стілець з нахилом вперед, кладуть руки на коліна і закривають очі. Пацієнти поплескують себе по колінах руками, і коли це стає напівавтоматичною дією, починають 
гарчати або видавати утробний звук. Передбачається, що пацієнти дозволяють звукам ставати все голоснішими, а поплескування все твердішими, допоки не виплеснеться вся накопичена лють, що допомагає їм вивільнити внутрішню напругу.

Tретій eman спрямований на підвищення сенситивності до власного тіла, зняття тілесного напруження, викликаного негативними відчуттями, емоціями. Ефективними на цьому етапі $€$ такі вправи: «вивільнення рухової активності», «зняття затиску». Вправа «вивільнення рухової активності» передбачає, що пацієнти (діти та сім'ї, що пережили травмуючи події) встають, розслабляються, подумки прислуховуються до найбільш напружених ділянок тіла і роблять обережні рухи цими ділянками. Вправа «зняття затиску» полягає в тому, що пацієнти сідають у незручну позу, зосереджують увагу на м'язовому затиску i розслабляють його зусиллям волі.

Висновки. Відтак, для роботи з дітьми та сім'ями, які постраждали від травмуючи подій, із застосуванням тілесно орієнтованої психотерапії необхідний комплексний підхід, що містить різні за спрямованістю методи зняття напруги, застосування яких дає змогу досягти повного розслаблення і розглянути життєві труднощі з іншого аспекту.

Таким чином, основними позитивними ефектами, що виникають у результаті застосування тілесно зорієнтованої психотерапії у роботі з дітьми та сім'ями, які зазнали психотравмівних впливів, є:

- зниження рівня тривоги, підвищення і стабілізація настрою, підвищення активності і працездатності;

- зміна дезадаптивних установок особистості на основі усвідомлення витіснених емоційних переживань і отримання доступу до власних внутрішніх ресурсів;

- зняття м’язових затисків, які спричинені травмуючими подіями;

- забезпечення емоційної підтримки та прийняття;

- зниження рівня агресії, тривоги та занепокоєння;

- пом'якшення або повне зникнення психосоматичних симптомів (задишки, нейродерміту, астматичних нападів, енурезу, судомних нападів); 
- набуття дітьми і дорослими навичок подолання перешкод на фізичному рівні, що автоматично переноситься і на інші аспекти життя (соціальний та психологічний);

- підвищення стійкості до стресу через розширення рольового діапазону і розвиток навичок адекватного поведінкового реагування;

- стійка динаміка позитивних змін для психотичних та аутичних розладів, панічних атак, нападів люті, нічних жахів, фобій;

- поява в учасників відчуття тіла, його можливостей і тонусу;

- створення нових цілепокладаючих установок, спрямованих на відчуття задоволення від життя і досягнення гармонійного функціонування.

Перевагами тілесно орієнтованої психотерапії у роботі з дітьми та сім'ями, які зазнали психотравмівних впливів, перед іншими психотерапевтичними методами є:

1) ефективність при «закритості» пацієнта, зниження мотивації до лікування, при алексетімії, коли «мова тіла» є єдиною можливістю пацієнта розповісти про власні первинні внутрішні проблеми;

2) можливість зменшити захисні механізми опору;

3) вибудовування адекватного образу «Я» через практичний досвід міжособистісної взаємодії;

4) відносна простота і доступність освоєння навичок за відносно короткий період, що сприяють використанню їх для саморегуляції.

Тілесно орієнтована психотерапія у роботі 3 дітьми та сім'ями, які зазнали психотравмуючих впливів, високоефективна в межах короткострокової психотерапії та в якості довгострокової психотерапії в амбулаторних умовах, з акцентом на регулярному виконанні пацієнтами лікувально-профілактичного комплексу вправ і технік групової інтегративної тілесно орієнтованої психотерапії. 


\section{Список використаних джерел}

1. Баскаков В. Ю. Хрестоматия по телесно ориентированной психотерапии и психотехнике. Свободное тело. М.: Институт общегуманитарных исследований, 2004. 224 с.

2. Бутома Б. Г., Аристова Т. А. Применение телесно ориентированных методов психотерапии в комплексном лечении больных эндогенными психическими расстройствами. Обозрение психиатрии и медицинской психологии. 2012. № 3. С. 80-87.

3. Волженцева И. В. Методологические и теоретико-эмпирические аспекты полифункциональной регуляции психических состояний личности эмоциогенными способами: монография. Макеевка: МЭГИ; Донецк: Донбасс, 2012. $536 \mathrm{c.}$

4. Воробьева Е. А. Роль и место телесно ориентированных методов в работе с детьми. Междисииплинарные проблемы психологии телесносmu. 2004. № 5. C. 302-307.

5. Ігумнова О. Б. Генеза негативних психічних станів студентів та їх психокорекція: дис. ... канд. психол. наук: спец. 19.00.07 / Хмельницький національний університет. Хмельницький, 2014. 275 с.

6. Ревуцька I. В. Концептуальна модель корекції негативних психічних станів і психосоматичних розладів у дітей дошкільного віку засобами тілесно орієнтованої терапії. Психологічний часопис. 2018. Вип. 5 (15). С. 129141.

7. Ревуцька І. В. Концептуальний підхід до діагностування психосоматичних проявів у дітей дошкільного віку. Огляд. 2018. Вип. 2(45). С. 200-210.

8. Романчук О. Сім'я, що зцілює: основи терапевтичного батьківства дітей, що зазнали скривдження та емоційного занедбання. Львів: Колесо, 2011. $156 \mathrm{c.}$

9. Сандомирский М. С. Психосоматика и телесная психотерапия: Практическое руководство. М.: Независимая фирма «Класс», 2005. 592 с.

10. Сергеева Л. С. Телесно ориентированные методы в системе психотерапии больных затяжными неврозами: автореф. дис. ... канд. мед. наук: 14.00.18. СПб., 2011. 21 с.

11. Тимошенко Г. В., Леоненко Е. А. Работа с телом в психотерапии: практическое руководство. М.: Психотерапия, 2006. 480 с.

12. Шубина Е. В. Основы телесной терапии. Иллюстрированное руководство для профессионалов. СПб.: Наука и Техника, 2007. 240 с.

13. Bonanno G. A. Loss, trauma, and human resilience. Have we underestimated the human capacity to thrive after extremely aversive events? American psychologist. 2004. Vol. 59 (1). P. 203-238.

14. Cerfolio N. E. Multimodal Psychoanalytically Informed Aid Work with Children Traumatized by Chechen War. Journal of The American Academy of Psychoanalysis and Dynamic Psychiatry. 2009. Vol. 37 (4). P. 587-603.

15. Everly G. S., Lating J. M., Mitchell J. T. Innovations in group crisis intervention. Crisis Intervention / Ed. A. R. Roberts. Oxford University Press, 2005. $458 \mathrm{p}$. 
16. Gray M. J., Litz B. T., Maguen S. Acute psychological impact of disaster and large-scale trauma: limitations of traditional interventions and future practice recommendations. Prehospital and disaster medicine. 2014. Vol. 19 (1). P. $125-140$.

17. Röhricht F. Body-oriented psychotherapy: The state of the art in empirical research and evidence-based practice: A clinical perspective. Journal of Body, Movement \& Dance in Psychotherapy. 2009. Vol. 4 (2). P. 135-156.

\section{REFERENCES}

1. Baskakov V. Ju. (2004) Hrestomatija po telesnoorientirovannoj psihoterapii i psihotehnike. Svobodnoe telo. M.: Institut Obshhegumanitarnyh Issledovanij, 224 s. [in Russian]

2. Butoma B. G., Aristova T. A. (2012) Primenenie telesno-orientirovannyh metodov psihoterapii v kompleksnom lechenii bol'nyh jendogennymi psihicheskimi rasstrojstvami. Obozrenie psihiatrii i medicinskoj psihologii. № 3. S. 8087. [in Russian]

3. Volzhenceva I. V. (2012) Metodologicheskie i teoretiko-jempiricheskie aspekty polifunkcional'noj reguljacii psihicheskih sostojanij lichnosti jemociogennymi sposobami: monografija. Makeevka: MJeGI, Doneck: Donbass, 536 s. [in Russian]

4. Vorob'eva E. A. (2004) Rol' i mesto telesno-orientirovannyh metodov v rabote s det'mi. Mezhdisciplinarnye problemy psihologii telesnosti. № 5. S. 302-307. [in Russian]

5. Igumnova O. B. (2014) Geneza negativnih psihichnih staniv studentiv ta ïh psihokorekcija: dis. na zdob. nauk. stup. kand. psihol. nauk: spec. 19.00.07 / Hmel'nic'kij nacional'nij universitet. Hmel'nic'kij, 275 s. [in Russian]

6. Revutska I. V. (2018) Kontseptualna model korektsii nehatyvnykh psykhichnykh staniv i psykhosomatychnykh rozladiv u ditei doshkilnoho viku zasobamy tilesnooriientovanoi terapii. Psykholohichnyi chasopys. Vyp. 5 (15). S. 129141. [in Ukrainian]

7. Revutska I. V. (2018) Kontseptualnyi pidkhid do diahnostuvannia psykhosomatychnykh proiaviv u ditei doshkilnoho viku. Naukovyi zhurnal Ohliad. Vyp. 2(45). S. 200-210. [in Ukrainian]

8. Romanchuk O. (2011) Cimia, shcho ztsiliuie: osnovy terapevtychnoho batkivstva ditei, shcho zaznaly skryvdzhennia ta emotsiinoho zanedbannia. Lviv: Koleso, $156 \mathrm{~s}$. [in Ukrainian]

9. Sandomirskij, M. S. (2005) Psihosomatika i telesnaja psihoterapija: Prakticheskoe rukovodstvo. M.: Nezavisimaja firma «Klass», 592 s. [in Russian]

10. Sergeeva L. S. (2011) Telesno-orientirovannye metody v sisteme psihoterapii bol'nyh zatjazhnymi nevrozami: avtoref. diss.... kand. med. nauk 14.00.18. SPb. 21 s. [in Russian]

11. Timoshenko G. V., Leonenko E. A. (2006) Rabota s telom v psihoterapii: Prakticheskoe rukovodstvo. M: Psihoterapija, 480 s. [in Russian]

12. Shubina E. V. (2007) Osnovy telesnoj terapii. Illjustrirovannoe rukovodstvo dlja professionalov. SPb.: Nauka i Tehnika, 240 s. [in Russian] 
13. Bonanno G. A. (2004) Loss, trauma, and human resilience. Have we underestimated the human capacity to thrive after extremely aversive events? American psychologist. Vol. 59 (1). P. 203-238. [in English].

14. Cerfolio N. E. (2009) Multimodal Psychoanalytically Informed Aid Work with Children Traumatized by Chechen War. Journal of The American Academy of Psychoanalysis and Dynamic Psychiatry. Vol. 37 (4). P. 587-603. [in English].

15. Everly G. S., Lating J. M., Mitchell J. T. (2005) Innovations in group crisis intervention. Crisis Intervention / Ed. A. R. Roberts. Oxford University Press, 458 p. [in English].

16. Gray M. J., Litz B. T., Maguen S. (2014) Acute psychological impact of disaster and large-scale trauma: limitations of traditional interventions and future practice recommendations. Prehospital and disaster medicine. Vol. 19 (1). P. 125-140. [in English].

17. Röhricht F. (2009) Body-oriented psychotherapy: The state of the art in empirical research and evidence-based practice: A clinical perspective. Journal of Body, Movement \& Dance in Psychotherapy. Vol. 4 (2). P. 135-156. [in English].

\section{Hopkalo Yu.}

junior research scientist Laboratory of Applied Psychology

of Education, Ukrainian Scientific and Methodological Center

for Applied Psychology and Social Work

Vito-Litovsk Lane, b. 98-A, Kiev, Ukraine

\section{USING OF BODY-ORIENTED PSYCHOTHERAPY AS ONE OF THE METHODS IN WORKING WITH CHILDREN AND FAMILIES WHO HAVE SURVIVED TRAUMATIC EVENTS}

In the article it has been considered and substantiated the theoretical and methodological foundations of the organization of group forms of work with psychotrauma in persons who have suffered as a result of hostilities, based on the introduction of methods of body-oriented psychotherapy.

Body-oriented psychotherapy expands the possibilities of psychotherapeutic influence by considering the individual in the unity of its psychosocial and biological functioning.

Group methods in working with post-traumatic stress disorders in working with children and families in difficult life situations due to hostilities are a system of psychotherapeutic influence that optimally combines body-oriented psychotherapy with elements of symbol drama, 
psychological debriefing, behavioral methods of psychotherapy, dancemovement psychotherapy, art therapy, psycho training, pharmacotherapy and other methods aimed at working with clinical manifestations of psychotrauma.

The method of body-oriented psychotherapy in work with children and families affected by traumatic events can be a leader, both in working with distant clinical manifestations and to prevent the development of PTSD, in dealing with mental and physical aspects of functioning, resolving intrapersonal conflicts; determining the level of adequacy of self-perception and self-esteem; reducing the level of personal anxiety, mental tension, emotional lability.

Its using helps children and families who have experienced traumatic events, with the help of motor psychotechnics to more accurately recognize and verbalize their own emotions, relive their past emotional experiences, thereby expanding the scope of self-knowledge and forming a more emotionally beneficial attitude.

In addition, it makes a significant contribution to the further development of ideas about the mechanism of therapeutic action of psychotherapy, as changes that occur with clients (children and families who have experienced traumatic actions) and are the ultimate goal of psychotherapeutic effects affect different levels of body and personality.

Key words: persons affected by hostilities, psychotrauma, body-oriented psychotherapy, methods.

Статті надійшла до редакиї 30.11.2020 